\title{
Morphometric analysis of mice's ventricular myocardium submitted to androgenic anabolizing steroids use
}

\author{
ALVES, D. M., SILVA, M. S. O., ZAVAN, B., NOGUEIRA, D. A., \\ FERNANDES, G. J. M., ROSSI JUNIOR, W. C., ESTEVES, A.* \\ Departamento de Anatomia, Universidade Federal de Alfenas - Unifal, Rua Gabriel Monteiro da Silva, 700, \\ Centro, CEP 37130-000, Alfenas, MG, Brazil \\ *E-mail: aesteves@unifal-mg.edu.br
}

\begin{abstract}
Introduction: Androgenic anabolizing steroids (AAS) are a group of natural and synthetic compounds deriving from testosterone or one of its sub-products which are more and more used by young people for improving physical performance or for aesthetic reason. Complications, such as arteriosclerosis and acute myocardium infarction (AMI), have been reported in AAS' users, but the records about the ventricular anatomical structure of those users are few. Because of that, this study aimed to verify morphologic and quantitative morphometric possible alterations on mice's left ventricular myocardium submitted to their use. Materials and Methods: Thirty mice were divided into three 10-animals groups (group 1: received Deca-Durabolin ${ }^{\circledR}$; group 2: received Potenay ${ }^{\circledR}$; and group 3: received saline solution), each one of them composed by five males and five females, treated once a week and put to swimming thrice a week during one month. Results: Results revealed that there were no significant alterations in the quantity of muscle fibers in the animals treated with AAS but there were significant differences when comparing male-to-female mice and left ventricular area $(\mu \mathrm{m} 2)$. It was observed that mice in group 1 (Deca-Durabolin ${ }^{\circledR}$ ) presented a lesser left ventricular area when compared to those in group 3 (control) but, when analyzing cardiac muscle fibers morphologically, it was verified that the myocardium was looser and softer in drug-submitted animals, especially those in group 1 (Deca-Durabolin ${ }^{\circledR}$ ). Conclusion: There are effective significant differences when a morphologic and quantitative morphometric analysis is done concerning mice's left ventricular myocardium submitted to AAS.
\end{abstract}

Keywords: androgenic anabolic steroids, cardiac fibers, left ventricle, mice.

\section{Introduction}

Androgenic anabolizing steroids (AAS) are a group of natural and synthetic compounds deriving from testosterone or one of its sub-products (CUNHA, 2004).

Testosterone was first synthesized in 1935 and, since then, androgenic drugs became available for experimental and therapeutic purposes. Androgenic steroids are referred to male sexual hormones and can be defined as any substance that specifically produces male gonads growth (HANDA and PRICE, 2000).

Some authors state that androgenic hormones use for improving the physical performance occurred only in 1939 (THEIN, THEIN and LANDRY, 1995; SCOTT, WAGNER and BARLOW, 1996). However, there are reliable reports that this could have happened before, in 1896, when a BrownSéquard disciple, after self-administration of a testicular extract, observed a rising in his fingers' muscular strength (KUHN, 2002).

The first known AAS use intending the improvement of contest athletes' performance was in 1954, during a weight lifting competition in Vienna. Russian athletes that used such substances presented a highly satisfactory performance (ASSIS, 2002).

Nevertheless, it was only in the scenery of the Cold War that AAS use reached its summit. German Democratic politicians soon perceived that sport success would be a quick and lowcost way of making their little 17 million-inhabitants country recognized and world-widely reputed. Large investments were dispended aiming the improvement of athletes' performance, from systematic screening of young talents in schools to indiscriminate use of illegal drugs. All efforts were made in such an efficient way that security measures prevented them to be disclosed (FRANKE and BERENDONK, 1997).

During this period, German Democratic government sponsored and supported, in an extremely secret way, the development of a number of doctorate theses concerning effects, reversible and irreversible damages consequent to the supervised administration of high doses of AAS and some peptide hormones to students and elite's athletes. Professionals involved in these researches (scientists, physicians and sport coaches) violated all medical, scientific and ethic precepts. Athletes were told that they were receiving "vitamin pills" (Turinabol-Oral ${ }^{\circledR}$ ), and when AAS injections (esters of testosterone and nandrolone) were necessary that those were for prophylactic meaning.

Professional and amateur athletes were oriented to make no comments concerning what was going on to relatives and friends (YESALIS, COURSON and WRIGHT, 1993). In 1968, during preparatory trainings for Olympiad, German Democratic Republic's officers crossed over another ethic barrier and administered androgenic hormones to female athletes. Since 1972, the little German Democratic Republic was constantly at the top of Olympic medal's ranking, beside USA and Russia. So, AAS that were firstly used for strength, power and speed sport modalities such as weight lifting, 
hammer throwing, swimming and short-distance running, soon became largely used also for other sport modalities (FRANKE and BERENDONK, 1997). Since then, their use has spread out not only in Germany but in other countries throughout the world.

Young people and adolescents are using these substances more and more to improve their physical performance or for aesthetic purpose and, therefore, steroids must be studied continuously in order to know their indiscriminate risks of use and consequences without medical follow-up, which are dose and time-using dependence, but their possible benefits yet. The use of such substances are still part of the competitive or non sport habitat, since many people still believe that Darwinian Law that says "only the fittest reach the highest level of participation" can be applied to it, although there was no evidence of AAS use in natural selection (NORTON and OLDS, 2001).

Owing to structural and behavioral similarities with human beings, it was decided to make this research using mice (ORLANDO, CARUSO, MOLINARO et al., 2007).

\section{Materials and Methods}

Thirty mice were used, divided into 3 groups of 10 animals each, 15 male and 15 female ones, in order to verify the morphologic and quantitative morphometric possible alterations of ventricular myocardium submitted to AAS use. The groups were divided as follows: group 1- 5 male and 5 female mice treated with Deca-Durabolin ${ }^{\circledR}$ in $0.5 \mathrm{mg} / 100 \mathrm{~g}$ per live weight dose; group 2 - 5 male and 5 female mice treated with Potenay ${ }^{\circledR}$ in $0.5 \mathrm{mg} / 100$ per weight dose ; and group $3-5$ male and 5 female mice treated with saline solution in the dose of 10 $\mathrm{mg} / \mathrm{kg}$ (control group). The animals received one dose per week during one month (4 weeks).

This research project was sent to the Research Ethics Committee and to the Animal Experimentation Ethics Committee of Federal University of Alfenas (UNIFAL-MG) (register 224/2009) for analysis. After, the approval of both committees, the experiment was carried out in the Department of Anatomy and in the Department of Cellular, Tissue and Developmental Biology of the same university.

Six hours after receiving AAS dose mice were put to swimming for 5 minutes (VIEIRA, 2003). The animals were weighted to follow up their corporal mass once a week (Table 1).
After euthanasia by Halothane ${ }^{\circledR}$ inhalation, mice’s thoraxes were opened and the hearts were completely withdrawn for recording organ's data: apex-base, right pulmonary surface, left pulmonary surface and ventral-dorsal measures. The hearts were identified, stored in glass-recipients and immersed in $4 \%$-formaldehyde solution for 3 weeks (RABINOWICZ, DEAN, PETETOT et al., 1999; RABINOWICZ, PETETOT, GARTSIDE et al., 2002). The specimens were processed following the pattern sequence for conventional histological procedures as alcohol-dehydration, xylol-diaphanization and paraffin-inclusion (TOLOSA, RODRIGUES, BEHMER et al., 2003 ) and each heart area was cut into $5 \mu \mathrm{m}$-thick slices by a Lupe ${ }^{\circledR}$ microtome.

After that hematoxylin eosin and blue-toluidine dyed to ease cardiac muscle fibers visualization and to mark each cell clear and individually for further counting. For quantitative analysis, we chose three distinct fields for each heart area (ventricle and septum), performing five cuts for each heart and counting muscle fibers in a x40 magnification light microscope. For each chosen field a mean was taken and a final one, concerning the five means, was recorded for statistic analysis (RABINOWICZ, PETETOT, GARTSIDE et al., 2002; KARILA, 2003; EVERTON et al., 2011). For left ventricle area $\left(\mu^{2}\right)$ analysis the software NIS- Elements BR 3.1 was used.

In order to evaluate the mean numbers of muscle fibers and the mean values of left ventricle areas, according to mice's gender and treatment imposed (investigated groups) it was used the variance analysis. When a significant difference $(\mathrm{p}<0.01)$ was observed among the groups while comparing the different variables the Tukey test was used to discriminate differences and/or similarities among the evaluated means.

\section{Results}

It was observed a significant weight gain in male mice, as shown in Table 1. Analyzing apex-base, right pulmonary surface, left pulmonary surface and ventral-dorsal heart measures, there were no significant differences concerning the various treatments $(\mathrm{p}>0.01)$, as shown in Table 2 .

Relating to mice's gender, there was a significant difference $(p<0.01)$ between male and female ones, while the relation between gender and treatment was not significant $(\mathrm{p}>0.01)$, as shown in Table 3 .

Table 1. Variance analysis for animals' weight gain $(\mathrm{g})$ during four weeks of treatment.

\begin{tabular}{|c|c|c|c|c|c|}
\hline & $1^{\text {st }}$ week & $2^{\text {nd }}$ week & $3^{\text {rd }}$ week & $4^{\text {th }}$ week & $\mathbf{P}$ \\
\hline \multicolumn{6}{|l|}{ Potenay $^{\circledR}$} \\
\hline Males & 32.0 & 33.6 & 35.2 & 36.4 & ${ }^{*} 0.01$ \\
\hline Females & 26.4 & 27.6 & 28.8 & 29.8 & ns \\
\hline \multicolumn{6}{|c|}{ Deca-Durabolin $^{\circledR}$} \\
\hline Males & 31.4 & 33.4 & 35.2 & 36.6 & $\# 0.01$ \\
\hline Females & 27.6 & 28.6 & 31.0 & 31.4 & ns \\
\hline \multicolumn{6}{|l|}{ Control } \\
\hline Males & 31.6 & 32.2 & 33.6 & 34.4 & ns \\
\hline Females & 30.6 & 30.8 & 32.0 & 33.0 & ns \\
\hline
\end{tabular}

ns $=$ not significant. ${ }^{*} p<0.05$ vs Potenay ${ }^{\circledR}$ females. $\# \mathrm{p}<0.05$ vs Deca-Durabolin ${ }^{\circledR}$ females. 
It was also observed that, when counting muscle fibers, the different treatments were not significant $(\mathrm{p}>0.01)$, as well as the relation among gender, treatment and fields (Table 4 ), and the difference between male and female mice $(\mathrm{p}=0.02)$, with a mean of 36.70 muscle fibers/field for the former and 29.75 muscle fibers/field for the latter (Figure 1 and 2).

There was also a significant difference relating to fibers for right ventricle, left ventricle and interventricular septum $(\mathrm{p}<0.01)$, as shown in Table 5 .

Table 2. Variance analysis of heart measures means $(\mathrm{cm})$ for different treatments.

\begin{tabular}{ccccc}
\hline & $\begin{array}{c}\text { Apex- } \\
\text { base }\end{array}$ & $\begin{array}{c}\text { Lateral } \\
\text { Surface }\end{array}$ & $\begin{array}{c}\text { Ventro- } \\
\text { dorsal }\end{array}$ & Result \\
\hline Potenay $^{\circledR}$ & 0.94 & 0.61 & 0.50 & $\mathrm{~A}$ \\
$\begin{array}{c}\text { Deca- } \\
\text { Durabolin }^{\circledR}\end{array}$ & 0.98 & 0.59 & 0.51 & $\mathrm{~A}$ \\
Control & 0.93 & 0.58 & 0.48 & $\mathrm{~A}$ \\
\hline
\end{tabular}

Means displaying the same letter do not differ from each other by Tukey test (1\% significance level).

Table 3. Variance analysis of heart measures means $(\mathrm{cm})$ for both sexes.

\begin{tabular}{cccc}
\hline & Apex-base & $\begin{array}{c}\text { Lateral } \\
\text { Surface }\end{array}$ & $\begin{array}{c}\text { Ventro- } \\
\text { dorsal }\end{array}$ \\
\hline Male & $1.00 \mathrm{a}$ & $0.60 \mathrm{a}$ & $0.53 \mathrm{a}$ \\
Female & $0.90 \mathrm{a}$ & $0.58 \mathrm{a}$ & $0.46 \mathrm{~b}$ \\
\hline
\end{tabular}

Means displaying the same letter do not differ from each other by Tukey test (1\% significance level).

Table 4. Variance analysis of muscle fibers' number means per field for different treatments.

\begin{tabular}{ccc}
\hline & Mean & Result \\
\hline Potenay $^{\circledR}$ & 35.29 & $\mathrm{~A}$ \\
Deca-Durabolin $^{\circledR}$ & 31.67 & $\mathrm{~A}$ \\
Control $^{\circledR}$ & 32.71 & $\mathrm{~A}$
\end{tabular}

Means displaying the same letter do not differ from each other by Tukey test (1\% significance level).

Table 5. Variance analysis of muscle fibers' number means per field for different heart areas.

\begin{tabular}{ccc}
\hline & Mean & Result \\
\hline Right ventricle & 24.68 & $\mathrm{~A}$ \\
Interventricular septum & 35.05 & $\mathrm{~B}$ \\
Left ventricle & 39.95 & $\mathrm{~B}$ \\
\hline
\end{tabular}

Means displaying the same letter do not differ from each other by Tukey test ( $1 \%$ significance level).

Table 6. Variance analysis of left ventricle area means $\left(\mu \mathrm{m}^{2}\right)$ for different treatments.

\begin{tabular}{ccc}
\hline & Mean & Result \\
\hline Potenay $^{\circledR}$ & $2,063,469$ & $\mathrm{Ab}$ \\
Deca-Durabolin $^{\circledR}$ & $1,617,123$ & $\mathrm{~B}$ \\
Controle $^{\circledR}$ & $2,454,649$ & $\mathrm{~A}$ \\
\hline
\end{tabular}

Means displaying the same letter do not differ from each other by Tukey test ( $1 \%$ significance level).
Concerning left ventricle area analysis there was a significant difference for the various treatments $(\mathrm{p}<0.01)$, as shown in Table 6. In relation to gender, there was no significant difference $(p>0.01)$, with a mean of $1,990,703 \mu \mathrm{m}^{2}$ for female and 2,099,458 $\mu^{2}$ for male ones.

Under morphologic analysis it was observed that deca hearttreated group presented looser muscle fibers when compared to control group, as displayed in Figures 1 and 3.

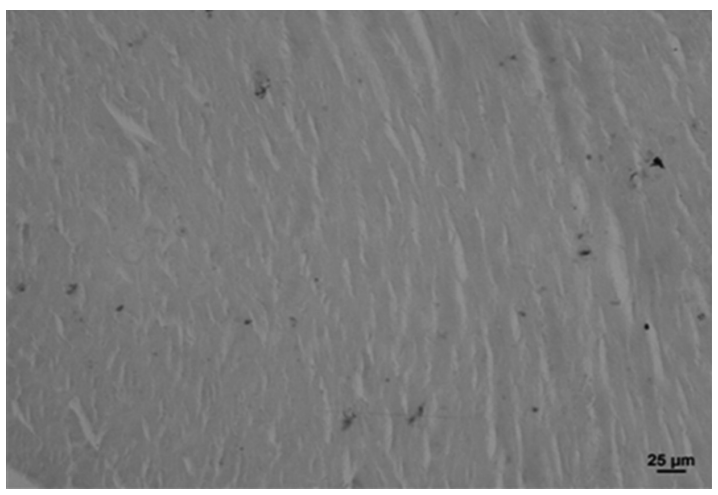

Figure 1. Photomicroscopy of a female mouse's left ventricle in control group. Cardiac muscle fibers are found juxtaposed. Toluidine.

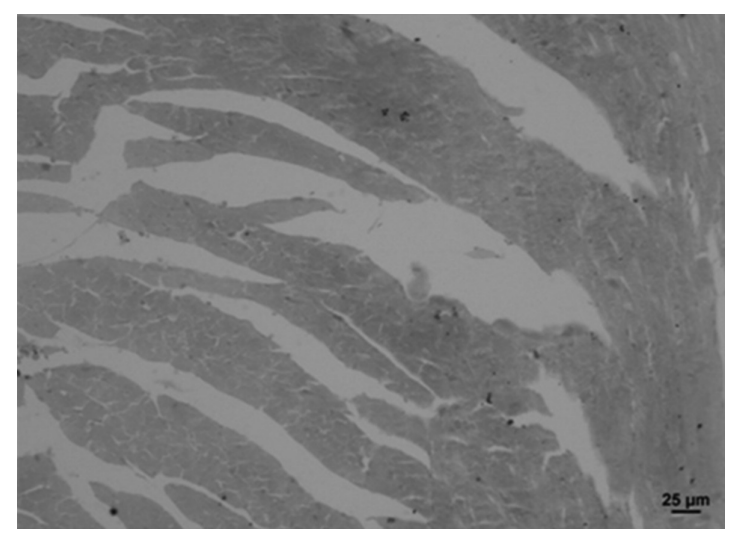

Figure 2. Photomicroscopy of a female mouse's left ventricle in Deca-Durabolin ${ }^{\circledR}$ group. Cardiac muscle fibers are found looser than those in control group. Toluidine.

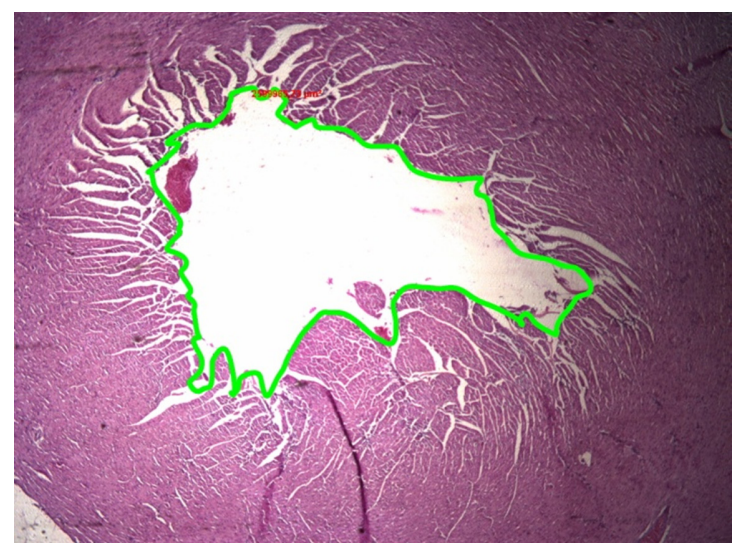

Figure 3. Photomicroscopy of a female mouse's left ventricle in control group. Area analysis. HE.x40. 


\section{Discussion}

It was not found in the compiled literature (KARILA, 2003) any studies about the relation between AAS and cardiac muscle fibers number but it is already known that their abusive use can lead to cardiovascular, metabolic and cerebral disturbances.

According to Carmo, Rosa, Koike et al. (2011), groups of rats submitted to anabolizing steroids associated to swimming training can present a decreased diastolic function.

Lunz, Oliveira, Neves et al. (2006), stated that the use of anabolizing steroids associated to exercises can generate an expressive rising of HSP 72 protein which plays a protection roll for the organism against stressing episodes such as myocardial infarction.

This study suggests that such substances can cause severe cellular/tissue heart injuries as it shows that there are significant differences in morphologic and quantitative morphometric analysis concerning the treatments involved.

As expected, in morphologic analysis one can observe that female mice have fewer muscle fibers than male ones. It can also be ascertained significant differences between ventricles and interventricular septum, being the right ventricle which presents fewer muscle fibers, probably due to its lesser blood flow.

According to the results displayed in Table 6, there was a significant decrease in ventricular diameter $\left(1617123 \mu \mathrm{m}^{2}\right)$ of mice submitted to Deca-Durabolin ${ }^{\circledR}$ treatment in comparison to control group $\left(2454649 \mu^{2}\right)$ and Potenay ${ }^{\circledR}$ group $\left(2063469 \mu \mathrm{m}^{2}\right)$ and this can be explained because Potenay ${ }^{\circledR}$ is just a stimulating drug and therefore, do not alter ventricle size; on the contrary, animals treated with Deca-Durabolin ${ }^{\circledR}$, which is an anabolizing steroid, have their ventricle diameter altered and this can elucidate the adverse effects occurring in indiscriminate use of such a drug as congestive cardiac failure in susceptible patients, arterial hypertension, myocardial rupture and even other tissue hypoxia.

\section{Conclusion}

The outcomes of this study allows the conclusion that AAS treatment did not bring significant changes to cardiac muscle fibers number, but there was a significant difference in group 1 mice (submitted to Deca-Durabolin ${ }^{\circledR}$ ) which presented a lesser left ventricle area than those in control group, besides the morphologic ascertaining of the presence of looser tissue. Morphologic and quantitative morphometric alterations can give rise to arterial hypertension, myocardial infarction, congestive cardiac failure in susceptible patients and they can also cause a diminished amount of oxygen reaching organs and tissue in all body systems including the nervous one.

\section{References}

ASSIS, WS. Efeitos da natação associada ao uso de dois esteróides anabolizantes (estanozolol e decanoato de nandrolona) sobre as fibras musculares oxidativas e glicoliticas do músculo gastrocnêmio de ratos. Rio Claro: Instituto de Biociências; Universidade Estadual Paulista "Júlio de Mesquita Filho", 2002. 181 p. [Master's Dissertation].

CARMO, EC., ROSA, KT., KOIKE, DC., FERNANDES, T., SILVA JUNIOR, ND., MATTOS, KC., WICHI, RB., IRIGOYEN, MCC. and OLIVEIRA, EM. A associação de esteroide anabolizante ao treinamento físico aeróbio leva a alterações morfológicas cardíacas e perda de função ventricular em ratos. Revista Brasileira de Medicina do Esporte, 2011, vol. 17, n. 2, p. 137-141. http:// dx.doi.org/10.1590/S1517-86922011000200014.
CUNHA, TS. Efeito do esteróide anabólico androgênico nandrolona sobre o metabolismo do glicogênio em ratos sedentários e treinados. Piracicaba: UNICAMP, 2004. 89 p. [Master's Dissertation].

FRANKE, WW. and BERENDONK, B. Hormonal doping and androgenization of athletes: a secret program of the German Democratic Republic government. Clinical Chemistry, 1997, vol. 43, n. 7, p. 1262-1279. PMid:9216474.

HANDA, JR. and PRICE, RH. Androgen action. In FINK, G. Encyclopedia of stress. New York: Academic Press, 2000. vol.1, p.183-188.

KARILA, T. Adverse effects of anabolic androgenic steroids on the cardiovascular, metabolic and reproductive systems of anabolic substance abusers. Helsinki: University of Helsinki, 2003. 70 f. [Master's Dissertation].

KUHN, CM. Anabolic steroids. Recent Progress in Hormone Research, 2002, vol. 57, n. 1, p. 411-434. http://dx.doi.org/10.1210/ rp.57.1.411. PMid:12017555.

LUNZ, W., OLIVEIRA, EC., NEVES, MT., FONTES, EP., DIAS, CM. and NATALI, AJ. Anabolic steroid-and exercise-induced cardiac stress protein (HSP72) in the rat. Brazilian Journal of Medical and Biological Research, 2006, July, vol. 39, n. 7, p. 889-893. http:// dx.doi.org/10.1590/S0100-879X2006000700006. PMid:16862279.

NORTON, K. and OLDS, T. Morphological evolution of athletes over the 20th century: causes and consequences. Sports Medicine, 2001, vol. 31, n. 11, p. 763-783. http://dx.doi.org/10.2165/00007256200131110-00001. PMid:11583103.

ORLANDO, R., CARUSO, A., MOLINARO, G., MOTOLESE, M., MATRISCIANO, F., TOGNA, G., MELCHIORRI, D., NICOLETTI, F. and BRUNO, V. Nanomolar concentrations of anabolic-androgenic steroids amplify excitotoxic neuronal death in mixed mouse cortical cultures. Brain Research, 2007, August 24, vol. 1165, p. 21-29. http://dx.doi.org/10.1016/j.brainres.2007.06.047. PMid:17662261.

RABINOWICZ, T., DEAN, DE., PETETOT, JM. and COURTENMYERS, GM. Gender differences in the human cerebral cortex: more neurons in males; more processes in females. Journal of Child Neurology, 1999, February., vol. 14, n. 2, p. 98-107. http://dx.doi. org/10.1177/088307389901400207. PMid:10073431.

RABINOWICZ, T., PETETOT, JM., GARTSIDE, PS., SHEYN, D., SHEYN, T. and DE, CM. Structure of the cerebral cortex in men and women. Journal of Neuropathology and Experimental Neurology, 2002, January, vol. 61, n. 1, p. 46-57. PMid:11829343.

SCOTT, DM., WAGNER, JC. and BARLOW, TW. Anabolic steroid use among adolescents in Nebraska schools. American Journal of Health-System Pharmacy, 1996, September 1, vol. 53, n. 17, p. 2068-2072. PMid:8870894.

THEIN, LA., THEIN, JM. and LANDRY, GL. Ergogenic aids. Physical Therapy, 1995, May, vol. 75, n. 5, p. 426-439. PMid:7732086.

TOLOSA, EMC., RODRIGUES, CJ., BEHMER, AO. and FREITAS, AGN. Manual de técnicas para histologia normal e patológica. São Paulo: Manole, 2003. 331 p.

VIEIRA, RP. Estudo do decanoato de nandrolona sobre o fígado de ratos Wistar. São Paulo: Universidade do Vale do Paraíba, 2003. 63 p. [Master's Dissertation].

YESALIS, CE., COURSON, SP. and WRIGHT, JE. History of anabolic steroid in sport and exercise. In YESALIS, CE. Anabolic steroids in sport and exercise. Champaign: Human Kinetics, 1993. p. 51-71.

Received April 14, 2014 Accepted July 9, 2015 